\title{
Anti-inflammatory and antimicrobial constituents from the leaves of Villaria odorata
}

\author{
Mario A. Tan ${ }^{1,2 *}$, Regina Belen P. Callanta ${ }^{1}$, Carlo Chris S. Apurillo ${ }^{1}$, \\ Thomas Edison E. dela Cruz ${ }^{1,2}$, Grecebio Jonathan D. Alejandro ${ }^{1,2}$, E Mafel C. Ysrael $^{1,3}$ \\ ${ }^{1}$ Research Center for the Natural and Applied Sciences; ${ }^{2}$ College of Science; ${ }^{3}$ Faculty of Pharmacy \\ University of Santo Tomas, España Boulevard, 1015 Manila, PHILIPPINES
}

\begin{abstract}
Three iridoids (1-3) and a sesquiterpenoid (4) were isolated from the leaves of Villaria odorata, a Philippine endemic Rubiaceae species. The structures were elucidated based on NMR and MS and in comparison with the literature. The anti-inflammatory activity of 1$\mathbf{4}$ was evaluated against COX-II, while the MIC and MBC of $\mathbf{3}$ and $\mathbf{4}$ were determined using the microtiter plate dilution assay.
\end{abstract}

Keywords: Rubiaceae, Villaria, antiinflammatory, antimicrobial, MIC, MBC, COX-II

\section{INTRODUCTION}

The family Rubiaceae is considered to be the fourth largest angiosperm family in the world. With more than 13,000 species distributed to 611 genera [1], this coffee family is significant source of interesting and biologically-active secondary metabolites. Diverse structures of natural products from Rubiaceae include the alkaloids, terpenoids, fatty acids, flavonoids, iridoids, steroids, coumarins, and quinones. Pharmacological activities displayed by these compounds range from cytotoxic, antiinfectives, hepatoprotective, antioxidants, anti-inflammatory, anti-Alzheimer, and analgesic activities among others.

One of the Rubiaceae genera endemic in the Philippines is the Villaria Rolfe. Belonging to the tribe Hypobathreae, it is distributed in the

*To whom correspondence should be addressed mat0468@yahoo.com coastal areas and comprises of six endemic species which are either shrubs or small trees [2, 3]. These include Villaria acutifolia, V. fasciculiflora, V. glomerata, V. leyetensis, $V$. odorata, and $V$. uniflora. To date, only $\beta$ sitosterol, 4-hydroxybenzaldehyde, and villarinol have been identified from the genus Villaria [4]. In our continuing effort on the study of endemic and indigenous Philippine plants [57] including the family Rubiaceae [8, 9] with interesting biological activities, we have embarked on the isolation and biological evaluation of iridoids and a norsesquiterpenoid from the leaves of $V$. odorata. The COX-II inhibition and the antimicrobial activity of the isolated compounds are reported herein.

\section{Materials AND METHOdS}

Plant material. Fresh leaves of V. odorata were collected from Cagsiay Uno, Mauban, Quezon, Philippines in April 2011. The identity of the plant 
was confirmed by one of the authors (GJDA) and a voucher specimen (USTH 5033) was deposited at the UST Herbarium, Research Center for the Natural and Applied Sciences, University of Santo Tomas.

Extraction and isolation. Air-dried and ground leaves of V. odorata $(1.18 \mathrm{~kg})$ were soaked thrice for a total of $7.6 \mathrm{~L}$ dist. $\mathrm{MeOH}$ at room temperature and filtered. The combined filtrates were concentrated under reduced pressure to obtain the crude extract (70 g). The crude extract was suspended in water and partitioned sequentially with hexane $(3 \times 100 \mathrm{~mL}), \mathrm{CH}_{2} \mathrm{Cl}_{2}$ $(4 \times 100 \mathrm{~mL})$ and $n-\mathrm{BuOH}(3 \times 50 \mathrm{~mL})$ to afford the semi-crude extracts. The $\mathrm{CH}_{2} \mathrm{Cl}_{2}$ extract was subjected to silica gel gravity column chromatography (CC) using gradient of $\mathrm{CH}_{2} \mathrm{Cl}_{2} /$ $\mathrm{MeOH}$ to yield four pooled sub-fractions $\left(\mathrm{V}_{\mathrm{A}}\right.$, $139.8 \mathrm{mg} ; \mathrm{V}_{\mathrm{B}}, 84.8 \mathrm{mg} ; \mathrm{V}_{\mathrm{C}}, 307.3 \mathrm{mg} ; \mathrm{V}_{\mathrm{D}}, 374 \mathrm{mg}$ ). Fraction $\mathrm{V}_{\mathrm{A}}$ was subjected to silica gel gravity $C C$ to give fractions $V_{A} 1-V_{A}$ 3. Fraction $V_{A} 1$ was purified using silica gel flash CC ( $90 \%$ EtOAc in hexane) to afford compound $\mathbf{1}$ (10 $\mathrm{mg}$, colorless oil). Fraction $\mathrm{V}_{\mathrm{C}}$ was subjected to silica gel gravity CC (30\% $\mathrm{CHCl}_{3}$ in EtOAc) obtaining compound 2 (15 mg, colorless oil) and subfractions $\mathrm{V}_{\mathrm{C}} 1-\mathrm{V}_{\mathrm{C}}$. Fraction $\mathrm{V}_{\mathrm{C}} 5$ was purified using silica gel flash CC ( $2 \% \mathrm{CHCl}_{3}$ in EtOAc) to afford compound 4 (6.5 mg, colorless oil). Fraction $\mathrm{V}_{\mathrm{D}}$ was subjected to silica gel gravity $\mathrm{CC}$ using gradient of $\mathrm{CHCl}_{3} / \mathrm{MeOH}$ to obtain sub-fractions $V_{D} 1-V_{D} 4$. Fraction $V_{D} 1$ was purified using silica gel flash $\mathrm{CC}(5 \% \mathrm{MeOH}$ in EtOAc) to afford compound 2 (5 mg, colorless oil) and compound 3 (8 mg, colorless oil).

Determination of antimicrobial activity. The minimum inhibitory concentration (MIC) and minimum bactericidal concentration (MBC) of the different compounds were determined using microtiter plate dilution assay. Extracts were diluted to a concentration of $1 \mathrm{mg} / \mathrm{mL}$, placed in microwells, then serially diluted (1:2) into eight wells to a final volume of $100 \mu \mathrm{L}$ for each test organism. Three bacteria were used for the assay: Staphylococcus aureus ATCC 25923, Escherichia coli ATCC 25922, and Pseudomonas aeruginosa ATCC 27853. A $100 \mu \mathrm{L}$ of bacterial suspension $\left(1.5 \times 10^{8} \mathrm{CFU} /\right.$ $\mathrm{mL}$ ) was added to each well and incubated at $37^{\circ} \mathrm{C}$ for $24 \mathrm{~h}$. The concentration in the last well with no growth after $24 \mathrm{~h}$ was reported as the MIC. All wells with no growth were then subcultured into nutrient agar (NA) plates to determine the MBC. The lowest concentration of extract which did not show bacterial growth in the NA plates after $24 \mathrm{~h}$ was reported as the MBC. All setups were done in triplicate for each of the compounds.

\section{Determination of the COX percentage} inhibition. The COX-II percentage inhibition of the compounds was determined using the microtiter plate colorimetric COX inhibitor screening assay kit. For the blank wells, $160 \mu \mathrm{L}$ assay buffer, $10 \mu \mathrm{L}$ heme, and $10 \mu \mathrm{L}$ AR grade $\mathrm{MeOH}$ (used to dissolve the compound) were added. For the $100 \%$ initial activity wells, $150 \mu \mathrm{L}$ assay buffer, $10 \mu \mathrm{L}$ heme, $10 \mu \mathrm{L}$ COX-II enzyme, and $10 \mu \mathrm{L}$ AR grade $\mathrm{MeOH}$ were added. For the inhibitor wells, $150 \mu \mathrm{L}$ assay buffer, $10 \mu \mathrm{L}$ heme, $10 \mu \mathrm{L}$ COX-II enzyme, and $10 \mu \mathrm{L}$ of the compound dissolved in AR grade $\mathrm{MeOH}$ were added. The plate was shaken for $10 \mathrm{~s}$ and incubated for $5 \mathrm{~min}$ at $25^{\circ} \mathrm{C}$. Then $20 \mu \mathrm{L}$ colorimetric substrate solution and $20 \mu \mathrm{L}$ arachidonic acid were added to the wells. The plate was shaken and incubated for precisely $2 \mathrm{~min}$ at $25^{\circ} \mathrm{C}$ before the absorbance was read at $590 \mathrm{~nm}$.

\section{Results AND Discussion}

Structures of compounds 1-4. Chromatographic purification of the $V$. odorata extract led to the isolation and identification of the three iridoids morindolide (1), hydrophylin A (2), and hydrophylin B (3), and a norsesquiterpenoid, vomifoliol (4). The structures (Fig. 1) were elucidated based on 1D and 2D NMR, MS and by comparison with literature data. 


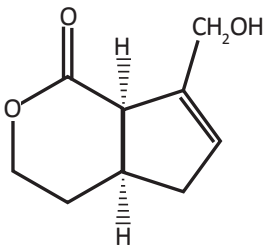

1

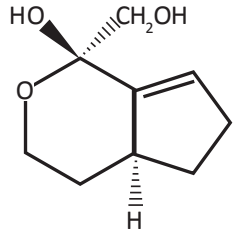

2

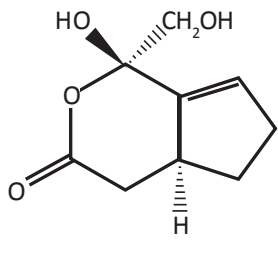

3

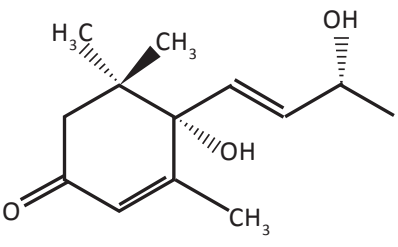

4

Figure 1. Isolated compounds from V. odorata

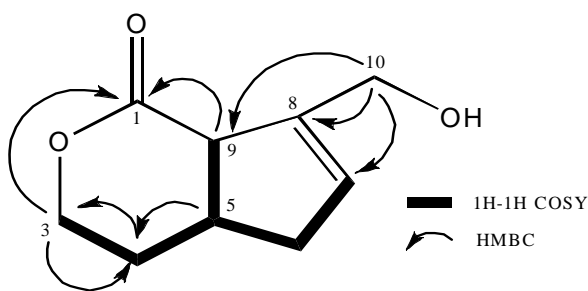

Figure 2. COSY and selected $\mathrm{HMBC}(\mathrm{H} \rightarrow \mathrm{C})$ correlations of 1

Morindolide (1) was isolated as colorless oil. The ${ }^{1} \mathrm{H}$ - and ${ }^{13} \mathrm{C}$-NMR (in $\mathrm{CDCl}_{3}$ ) spectra showed the presence of an olefinic group (5.78, 1H, br s, H-7; 129.1, CH, C-7; 140.0, C, C-8), a lactone carbonyl (173.0, C-1), and two oxygenated methylenes $(4.39,1 \mathrm{H}, \mathrm{m}, \mathrm{H}-3 \mathrm{a}, 4.28$, $1 \mathrm{H}, \mathrm{m}, \mathrm{H}-3 \mathrm{~b}, 67.2, \mathrm{CH}_{2}$, C-3; 4.28, m, $\mathrm{H}_{2}-10$, 60.6, $\left.\mathrm{CH}_{2}, \mathrm{C}-10\right)$. The ${ }^{1} \mathrm{H}-{ }^{1} \mathrm{H}$ COSY spectrum indicates a continuous spin system from $\mathrm{H}_{3}-\mathrm{H}_{4}-\mathrm{H}_{5}-\mathrm{H}_{6}-\mathrm{H}_{7}$, and $\mathrm{H}_{5}-\mathrm{H}_{9}$ (Fig. 2). Significant HMBC correlations include $\mathrm{H}-3(\delta 4.39)$ with $\mathrm{C}-1$ $(\delta 173.0) ; \mathrm{H}-9(\delta 3.76)$ with C-1, C-7 $(\delta 129.1)$, and C-8 ( $\delta 140.0)$; H-10 with C-7, C-8, and C-9 (Fig. 2). Thus, the structure was elucidated as shown in $\mathbf{1}$ and identified as morindolide [10].

Hydrophylin A (2) was isolated as colorless oil. The ${ }^{1} \mathrm{H}$ and ${ }^{13} \mathrm{C}$ NMR (in $\mathrm{CD}_{3} \mathrm{OD}$ ) indicated the presence of an olefinic group $(\delta 5.83,1 \mathrm{H}$, br s, H-6; $\delta$ 131.4, C-6; $\delta 143.9$, C-6a), an acetal quaternary carbon $(\delta 100.0, \mathrm{C}-7)$, and two oxygenated methylenes $(\delta 3.65,1 \mathrm{H}, \mathrm{d}, \mathrm{J}=11.5, \mathrm{H}-$ 8a; $\delta 3.61,1 \mathrm{H}, \mathrm{d}, \mathrm{J}=11.5, \mathrm{H}-8 \mathrm{~b} ; \delta$ 66.7, C-8) and $(\delta 3.88,1 \mathrm{H}, \mathrm{m}, \mathrm{H}-2 \mathrm{a} ; \delta 3.59,1 \mathrm{H}, \mathrm{m}, \mathrm{H}-2 \mathrm{~b} ; \delta$ 67.8,
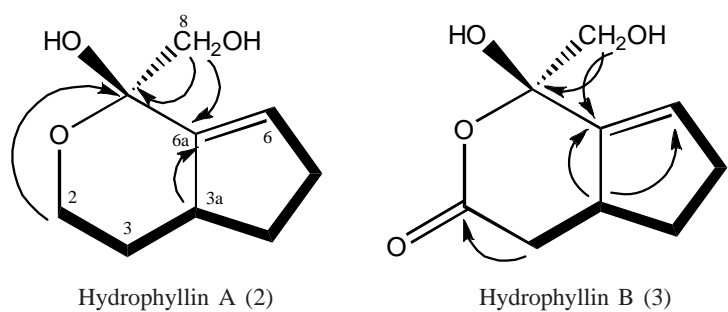

Figure 3. $\mathrm{COSY}$ and selected $\mathrm{HMBC}(\mathrm{H} \rightarrow \mathrm{C})$ in compounds $\mathbf{2}$ and $\mathbf{3}$

C-2). Structure elucidation of 2 was based on 2D-NMR (Fig. 3). A continuous spin system in the COSY was observed from $\mathrm{H}_{2}-\mathrm{H}_{3}-\mathrm{H}_{3 \mathrm{a}}-\mathrm{H}_{4}-\mathrm{H}_{5}-$ $\mathrm{H}_{6}$. Important $\mathrm{HMBC}$ correlations in 2 were observed as follows: $\mathrm{H}-2 \rightarrow \mathrm{C}-7$; H-6 $\rightarrow \mathrm{C}-7$, C6a; H-6 $\rightarrow$ C-6a; H-5 $\rightarrow$ C-6, C-6a. Hence, the structure of $\mathbf{2}$ was identified as hydrophylin A and was in exact match with the literature data [11].

Hydrophylin B (3) showed the presence of a carbonyl lactone ( $\delta 179.8, \mathrm{C}-2)$, an acetal carbon $(\delta 102.4, C-7)$, and an olefinic group $(\delta 5.99,1 \mathrm{H}$, br s, C-6; $\delta 133.5$, C-6, $\delta$ 143.4, C-6a). 1H-1HCOSY elaborated the $\mathrm{H}-3 \rightarrow \mathrm{H}-3 \mathrm{a} \rightarrow \mathrm{H}-4 \rightarrow \mathrm{H}-5 \rightarrow \mathrm{H}-6$ spin system. Significant HMBC correlations in 2 are shown in Fig. 3 as follows: $\mathrm{H} 3 \rightarrow \mathrm{C}-2$, H3a $\rightarrow$ C-6, C-6a, H-8C-7, C-6a. Thus, 3 was depicted as hydrophylin B [11].

Compound $\mathbf{4}$ exhibited an NMR spectrum which indicated two olefinic groups, one coupled with a methyl (allylic coupling) $(\delta 5.91,1 \mathrm{H}$, br s, $\mathrm{H}-4$; $\delta$ 127.0, C-4; $\delta$ 162.5, C-5; $\delta$ 1.90, 3H, d, J=1.5, H- 


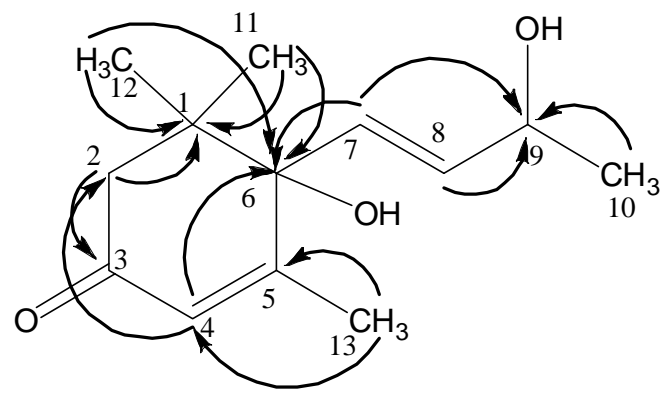

Figure 4. $\mathrm{HMBC}$ correlations $(\mathrm{H} \rightarrow \mathrm{C})$ in compound 4

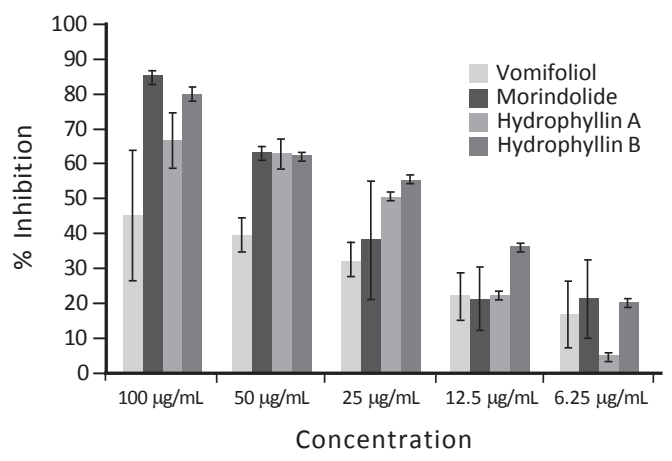

Figure 5. Anti-inflammatory activity of the isolated compounds

Table 1: Percentage inhibition of compounds 1-4 against COX-II

\begin{tabular}{c|c|c|c|c|c}
\hline & $100 \mu \mathrm{g} / \mathrm{mL}$ & $50 \mu \mathrm{g} / \mathrm{mL}$ & $25 \mu \mathrm{g} / \mathrm{mL}$ & $12.5 \mu \mathrm{g} / \mathrm{mL}$ & $6.25 \mu \mathrm{g} / \mathrm{mL}$ \\
\hline $\mathbf{1}$ & $84.94 \pm 0.88$ & $62.73 \pm 1.76$ & $37.96 \pm 16.84$ & $20.98 \pm 8.84$ & $20.77 \pm 11.00$ \\
\hline $\mathbf{2}$ & $66.25 \pm 7.53$ & $62.32 \pm 1.76$ & $50.09 \pm 1.40$ & $21.79 \pm 0.71$ & $4.28 \pm 1.30$ \\
\hline $\mathbf{3}$ & $79.54 \pm 1.16$ & $62.16 \pm 0.58$ & $54.90 \pm 0.85$ & $35.67 \pm 1.28$ & $19.88 \pm 0.58$ \\
\hline $\mathbf{4}$ & $44.58 \pm 18.45$ & $39.17 \pm 4.52$ & $31.77 \pm 5.00$ & $21.59 \pm 6.70$ & $16.40 \pm 9.60$ \\
\hline
\end{tabular}

Table 2. Antimicrobial assay of Hydrophyllin A (3) and Hydrophyllin B (4)

\begin{tabular}{c|c|c|c|c|c|c}
\hline \multirow{2}{*}{ Compound } & \multicolumn{3}{|c|}{ MIC $(\mu \mathrm{g} / \mathrm{mL})$} & \multicolumn{3}{c}{ MBC $(\boldsymbol{\mu g} / \mathbf{m L})$} \\
\cline { 2 - 7 } & E. coli & P. aeruginosa & S. aureus & E. coli & P. aeruginosa & S. aureus \\
\hline $\mathbf{3}$ & 125 & 250 & 250 & 500 & $>500$ & 500 \\
\hline $\mathbf{4}$ & 125 & 250 & 250 & 500 & 500 & 500 \\
\hline
\end{tabular}

$13 ; \delta 18.9, \mathrm{C}-13)$; and the other having a trans orientation $(\delta 5.79,1 \mathrm{H}, \mathrm{d}, \mathrm{J}=15.7, \mathrm{H}-7 ; \delta 5.86,1 \mathrm{H}$, dd, J=15.7, 5.1, H-8; $\delta$ 135.7, C-7; $\delta$ 129.0, C-8). A lactone carbonyl was observed at d 197.9 (C-3), an oxygenated methine at $\delta 4.42,1 \mathrm{H}, \mathrm{m}, \mathrm{H}-9$; $\delta$ 68.1, C-9; while methyl groups were observed at $\delta 1.01$ (3H, s, H-11), $\delta 1.09$ (3H, s, H-12), and $\delta 1.31(3 \mathrm{H}, \mathrm{d}, \mathrm{J}=6.3, \mathrm{H}-10)$. Analysis of the COSY spectrum showed a correlation of $\mathrm{H}-7 \rightarrow \mathrm{H}-8 \rightarrow \mathrm{H}-$ $9 \rightarrow \mathrm{H}-10$ protons. HMBC correlations (Fig. 4) were deduced as follows: $\mathrm{H}-12$ and $\mathrm{H}-11$ with $\mathrm{C}$ 1 ( $\delta 41.1)$, C-6 ( $\delta 79.0)$; the $\mathrm{H}-2$ geminal protons ( $\delta 2.25,1 \mathrm{H}, \mathrm{d}, \mathrm{J}=16.8$ and 2.45, $1 \mathrm{H}, \mathrm{d}, \mathrm{J}=16.8$ ) with C-1, C-3, C-4; H-4 with C-6. Hydroxyl groups were assigned to C-9 and C-6 as evidenced by the low-resolution electron-impact mass spectra which exhibited $\mathrm{M}^{+}$at $\mathrm{m} / \mathrm{z} 224$, the base peak at $\mathrm{m} / \mathrm{z} 83$ (100\%), and $\left[\mathrm{M}-\mathrm{H}_{2} \mathrm{O}\right]^{+}$at $\mathrm{m} / \mathrm{z} 206$ (1.5\%) and the carbon signals at $\mathbf{d} 68.1$ (CH unit) and 79.0 (C unit). Thus, the structure of 4 was elucidated as vomifoliol [12].

Biological evaluation on the isolated compounds. The family Rubiaceae is known to contain iridoids and its glycosides with significant anti-inflammatory activity [13]. The isolated metabolites in this study were tested for their inhibition against COX-II, an enzyme which is responsible for pain and inflammation (Fig. 5, Table 1). Results showed $(n=3)$ that increasing the concentration also increases their inhibition. At $100 \mu \mathrm{g} / \mathrm{mL}$, morindolide (1) showed 
the highest inhibition at $84.94 \% \pm 0.88$ followed by hydrophylin B (3) with $79.54 \% \pm 1.16$ inhibition. The synthetic compound DuP-697 was used as the positive control which showed a $94.38 \% \pm 3.15$ inhibition at $50 \mu \mathrm{g} / \mathrm{mL}$.

The MIC and MBC (Table 2) for $\mathbf{3}$ and $\mathbf{4}$ were also determined using the microtiter plate dilution assay. The MIC refers to the lowest concentration of a compound that will inhibit the visible growth of a microorganism after overnight incubation while MBC refers to the lowest concentration of a compound that will prevent the growth of an organism after subculture in an antibiotic-free media [14]. Results revealed a moderate activity for both compounds $\mathbf{3}$ and $\mathbf{4}$ against the three organisms as indicated by their MIC values. Our previous report on $\mathbf{4}$ also showed a moderate antibacterial activity against Klebsiella oxytoca [9].

These results showed that $V$. odorata, an endemic Philippine plant, to be a promising source of biologically-active secondary metabolites. These may serve as lead compounds which can be used in synthesisstructure activity relationship studies.

\section{CONCLUSION}

Phytochemical investigation of $V$. odorata, a Philippine endemic Rubiaceae species, led to the identification of three iridoids, morindolide (1), hydrophylin A (2), and hydrophylin B (3) and a norsesquiterpenoid, vomifoliol (4). All compounds were identified for the first time from $V$. odorata. Evaluation of the anti-inflammatory and antimicrobial activities of compounds 1-4 showed the promising potential of $V$. odorata as new sources of biologically-active natural products.

\section{ACKNOWLeDgment}

The Research Center for the Natural and Applied Sciences is gratefully acknowledged for the research grant.

\section{REFERENCES}

[1] Davis A, Govaerts R, Bridson D, Ruhsam M, Moat J, Brummitt N. A global assessment of distribution, endemism, and taxonomic effort in the Rubiaceae. Annals of the Missouri Botanical Garden 2009; 96:68-78.

[2] Arriola A, Alejandro GJD. A new species of Villaria (Octotropideae, Rubiaceae) from Luzon, Philippines including its conservation status. Phytotaxa 2013; 111:57-60.

[3] Mulyaningsih T, Ridsdale CE. An additional species of Villaria Rolfe (Rubiaceae) from the Philippines. Reinwardtia 2004; 12:195-197.

[4] Macabeo APG, Avila JA, Alejandro GJD, Franzblau SC, Kouam SF, Hussain H, Krohn K. Villarinol, a new alkenoyloxyalkenol derivative from the endemic Philippine Rubiaceae species Villaria odorata. Nat. Prod. Commun. 2012; 7:779-780.

[5] Choa JB, Dacanay AC, Tan MA. Antibacterial and mosquito larvicidal activity of Ficus casiguranensis and Ficus camarinensis leaves. J. Chem. Pharm. Res. 2014; 6:1351-1354.

[6] Tan MA, Nonato MG, Kogure N, Kitajima M, Takayama H. Secondary metabolites from Pandanus simplex. Biochem. Sys. Ecol. 2012; 40:4-5.

[7] Tan MA, Takayama H, Aimi N, Kitajima M, Franzblau SC, Nonato MG. Antitubercular triterpenes and phytosterols from Pandanus tectorius Soland. var. laevis. J. Nat. Med. 2008: 62:232-235.

[8] Tan MA, Concepcion CN, Alejandro GJD, Takayama $\mathrm{H}$. Chemotaxonomic relevance of the constituents from the leaves of Rothmannia merrillii. J. Chem. Pharm. Res. 2014; 6:779781.

[9] Tan MA, Eusebio JA, Alejandro GJD. Chemotaxonomic implications of the absence of alkaloids in Psychotria gitingensis. Biochem. Sys. Ecol. 2012; 45:20-22.

[10] Yoshikawa M, Yamaguchi S, Nishisaka H, Yamahara J, Murakami N. Chemical constituents of Chinese natural medicine, Morindae Radix, the dried roots of Morinda officinalis How.: structures of morindolide and morofficinaloside. Chem. Pharm. Bull. 1995: 43:1462-1465.

[11] Zeng Y, Mei W, Zhao Y, Dai H. Two new noriridoids from Scyphiphora hydrophyllacea. Zeitschrift für Naturforschung 2008; 63b:108110. 
Tan MA, Callanta RBP, Apurillo CCS, dela Cruz TEE, Alejandro GJD, \& Ysrael MC

| Acta Manilana 62 (2014)

[12] Hammami S, Ben Jannet H, Bergaoui A, Ciavatta L, Cimino G, Mighri Z. Isolation and structure elucidation of a flavanone, a flavanone glycoside and vomifoliol from Echiochilon fruticosum growing in Tunisia. Molecules 2004; 9:602-608.

[13] Inouye $H$, Takeda $Y$, Nishimura $H$, Kanomi $A$, Okuda T, Puff C. Chemotaxonomic studies of Rubiaceous plants containing iridoid glycosides. Phytochem. 1988; 27:2591-2598.
[14] Andrews JM. Determination of minimum inhibitory concentrations. J. Antimicrob. Chemother. 2001; 48:5-16. 